\section{Upscaling the estimation of surface-fire rate of spread in maritime pine (Pinus pinaster Ait.) forest}

\section{Paulo M Fernandes}

The prediction of the forward rate of forest fire spread is crucial to fire modeling and fire management. An empirical equation is available to estimate the rate of spread of surface fires in maritime pine stands from local fuel, terrain and weather conditions. However, the equation was primarily developed from experimental small fires under mild weather conditions. The ability to predict the spread rate of wildfires is examined. Underestimation was generalized, with a mean observed-to-predicted spread rate ratio of 2.64 , which is proposed to adjust the rate of spread equation for fire-modelling research applications.

\section{Keywords: Fire Behaviour, Fire Modelling, Surface Fire, Pinus Pinaster}

\section{Introduction}

The prediction of forest fire behavior characteristics finds application in several aspects of fire research and fire management. The ability to predict fire spread rate, i.e., the linear rate of advance of the fire front, is at the core of fire behavior prediction systems and makes possible estimating other fire behavior metrics, namely flame length (or height) and fireline intensity. Practical and reliable estimation of fire behavior descriptors is currently restricted to the use of empirical or semi-empirical equations that are developed from or validated with field data (Sullivan 2009).

A comprehensive experimental burning program in northern Portugal resulted in the development of equations that describe firespread rate and other fire behavior characteristics in the surface fuel complex of maritime pine (Pinus pinaster Aiton 1789) stands (Fernandes et al. 2009). These equations have been integrated in PIroPinus, a spreadsheet application developed to support prescribed burning planning (Fernandes et al 2012). The forward fire spread rate $R$ (m $\mathrm{min}^{-1}$ ) is estimated by an equation of the form (eqn. 1):

$$
R=a U^{b} \exp (c S+d M s) F D^{e}
$$

Centro de Investigação e de Tecnologias Agro-Ambientais e Tecnológicas (CITAB), Universidade de Trás-os-Montes e Alto Douro, Apartado 1013, 5001-801 Vila Real (Portugal)

@ Paulo M Fernandes (pfern@utad.pt)

Received: Mar 18, 2013 - Accepted: Oct 28, 2013

Citation: Fernandes PM, 2014. Upscaling the estimation of surface-fire rate of spread in maritime pine (Pinus pinaster Ait.) forest. iForest 7: 123-125 [online 2014-01-10] URL: http://www.sisef.it/iforest/contents/?id=ifor0992-007

Communicated by: Paola Mairota ted, $\sim 10$-m wide fires propagating over a distance of $\sim 10 \mathrm{~m}$, which for radiation-driven fires under calm or weak winds is expected to mirror the spread rate of larger fires (Wotton et al. 1999). Experimental burning programs in grassland, woodland and forest in Australia have shown that the potential rate of forward fire spread increases with head fire width (up to 50-300 m) until reaching an asymptote determined by wind speed (Cheney \& Gould 1995, Gould et al. 2003).

Eqn. 1 is now being applied to wildfire scenarios in the context of fire-modeling research (Ascoli et al. 2010, Castedo-Dorado et al. 2012), which departs from the original intended use, i.e., prescribed burning planning. This note examines the ability of the forward fire-spread equation of Fernandes et al. (2009) in predicting wildfire rate of spread in maritime pine forest.

\section{Materials and Methods}

Well-documented case studies of wildfire behavior in maritime pine stands were compiled from a review of the peer-reviewed and grey literature. Wildfire selection was dictated by (i) fire type, i.e., crown fires were excluded, and (ii) rate of fire spread and the inputs to eqn. 1 were either available or could be estimated from information in the reports. Fire-spread rate, wind speed and dead fuel moisture content were present in the Australian fire reports; for the Portuguese cases the former was calculated from the mapped fire perimeter and times of arrival, and the latter were derived from weather information using PIRoPinus (Fernandes et al. 2012). Terrain slope was reported in all study cases. Fuel depth was obtained from fuel loading as per Fernandes et al. (2002).

Rate of fire spread was estimated with eqn. 1 for the prevailing wildfire conditions. Deviation of predictions from the observed values was assessed by the absolute percent error (APE, Willmott 1982 - eqn. 2):

$$
A P E=\frac{\left|y_{i}-\hat{y}_{i}\right|}{y_{i}} \cdot 100
$$

where $y_{i}$ and $\hat{y}_{i}$ are the observed and the predicted fire-spread rates, respectively. Prediction accuracy was additionally expressed by the ratio of observed-to-predicted rate of fire spread. Linear and non-linear least squares regression was used to relate observed and predicted rates of fire spread.

\section{Results and Discussion}

The analysis considered six study cases (Tab. 1 and Tab. 2), two in Portugal and four in Australia, of which one corresponded to the experimental burning of three 1.3-ha plots (Burrows et al. 1988). Comparison between observed and predicted fire-spread rates is likely to be affected by substantial variation in terrain slope and wind direction. 
Tab. 1 - Case studies of surface-fire spread data in maritime pine stands. (W): wildfire; (E): experimental fire. Fire danger rating based on Sneeuwjagt \& Peet (1985) and Palheiro et al. (2006), respectively for Australia and Portugal.

\begin{tabular}{|c|c|c|c|c|c|c|}
\hline $\begin{array}{l}\text { Data } \\
\text { source }\end{array}$ & $\begin{array}{l}\text { Data } \\
\text { type }\end{array}$ & Location & Date & $\begin{array}{l}\text { Fire danger } \\
\text { rating }\end{array}$ & $\begin{array}{l}\text { Observation } \\
\text { time (hours) }\end{array}$ & $\begin{array}{c}\text { Fire size } \\
\text { (ha) }\end{array}$ \\
\hline McArthur (1965) & W & Gnangara, Western Australia & January 22, 1962 & Extreme & $1150-1700$ & 50 \\
\hline Macedo \& Sardinha (1987) & $\mathrm{W}$ & Praia da Raínha, Portugal & May 12, 1984 & Very High & $1400-1700$ & 850 \\
\hline Burrows et al. (1988) & $\mathrm{E}$ & Mullalyup, Western Australia & December 10, 1986 & Very High & $1030-1430$ & 1.3 \\
\hline Smith (1992) & $\mathrm{W}$ & Myalup, Western Australia & April 21, 1991 & Extreme & $1245-1400$ & 260 \\
\hline Burrows et al. (2000) & $\mathrm{W}$ & Gnangara, Western Australia & December 30, 1994 & Extreme & $1400-1930$ & 850 \\
\hline Ferreira \& Galante (2003) & W & Mata Nacional de Leiria, Portugal & August 2, 2003 & Very High & $1500-1900$ & 2578 \\
\hline
\end{tabular}

Tab. 2 - Surface-fire spread data in maritime pine stands collected in the literature. $(R)$ : rate of fire spread; (APE): absolute \% error; $(U)$ : in-stand wind speed at 1.5-2 m; $(S)$ : terrain slope; $\left(M_{\mathrm{S}}\right)$ : moisture content of fine dead surface fuels; $(F D)$ : fuel depth.

\begin{tabular}{|c|c|c|c|c|c|c|c|}
\hline \multirow{2}{*}{ Data source } & \multirow{2}{*}{$\begin{array}{c}U \\
\left(\mathrm{~km} \mathrm{~h}^{-1}\right)\end{array}$} & \multirow{2}{*}{$\begin{array}{c}S \\
\left(^{\circ}\right)\end{array}$} & \multirow{2}{*}{$\begin{array}{l}M_{\mathrm{S}} \\
(\%)\end{array}$} & \multirow{2}{*}{$\begin{array}{c}F D \\
(\mathbf{c m})\end{array}$} & \multicolumn{2}{|c|}{$R(\mathrm{~m} \mathrm{~min}-1)$} & \multirow{2}{*}{$\begin{array}{c}A P E \\
(\%)\end{array}$} \\
\hline & & & & & Pred. & Obs. & \\
\hline McArthur (1965) & 4 & 0 & 5 & 12 & 2.7 & 3.7 & 27 \\
\hline Macedo \& Sardinha (1987) & 8 & 11 & 7 & 70 & 11.5 & 13.8 & 16.7 \\
\hline Burrows et al. (1988) & 3.4 & 0 & 10.9 & 5 & 1.6 & 3 & 46.7 \\
\hline Smith (1992) & 11 & 0 & 7 & 8 & 4.7 & 21.8 & 78.4 \\
\hline Burrows et al. (2000) & 8.3 & 0 & 4.9 & 5 & 3.4 & 14.9 & 77.2 \\
\hline Ferreira \& Galante (2003) & 3 & 5 & 11 & 5 & 3.3 & 7.9 & 58.2 \\
\hline
\end{tabular}

However, this is not a relevant concern in this study, as slope was a minor fire-spread factor (Tab. 2) and maps in the reports portrayed wildfires of regular shapes, with high length-to-breadth ratio. Additionally, observation periods were relatively short (Tab. 1) minimizing variation in the fire environment and in fire behavior. Portuguese fires burned in litter-shrubs fuel complexes, while the Australian cases respect to litter. Fire spread rate was in all cases underpredicted, with a mean absolute percent error of $50.7 \%$ (Tab. 2 and Fig. 1). Underprediction varied by a factor of 1.2 to 4.6 , averaging 2.64 . The two fastest spreading wildfires were driven by a combination of relatively high wind speed and relatively low fuel moisture content and exhibited the highest ratios of observed-topredicted spread rate (4.6 in Smith 1992; 4.4 in Burrows et al. 2000). The fire-spread rate

Fig. 1 - Plot of observed versus predicted fire-spread rates in flat (slope $\leq 5^{\circ}$ ) terrain (data in Tab. 2). The fitted equation: $y=1.2208 \mathrm{e}^{0.6201 \mathrm{x}}$ accounts for $86 \%$ of the variability of observed fire-spread rate.

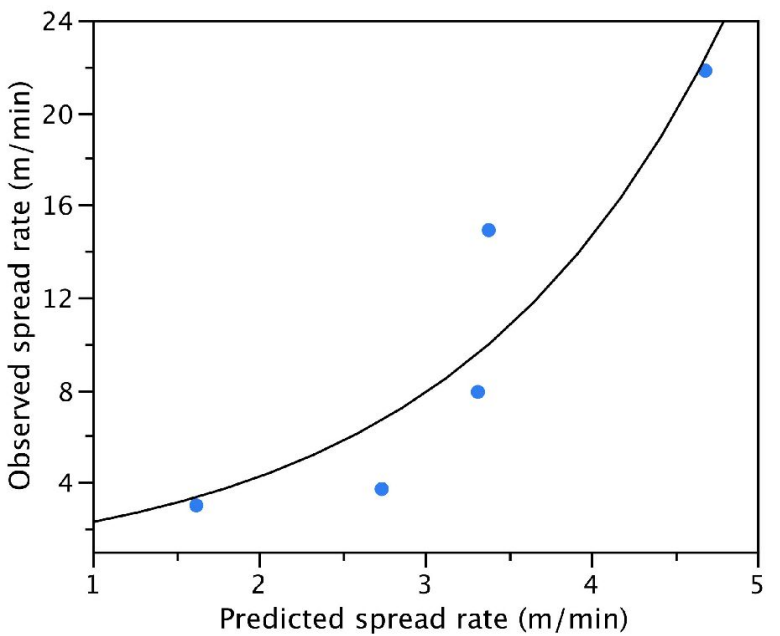

data set. The observed rate of fire spread in flat terrain (slope $\leq 5^{\circ}$, one fire excluded) is best related to the predicted value by means of an exponential function, which accounts for $86 \%$ of the existing variation (Fig. 1). This non-linear behavior implies that underestimation increases more than proportionally as fire weather conditions worsen, but note that a linear regression would fit the data nearly as well $\left(r^{2}=0.82\right)$. The ratio of observed-to-predicted fire-spread rate increases with wind speed $(r=0.9 ; \mathrm{p}=0.027)$. Likewise, eqn. 1 might underestimate the damping effect of fuel moisture, but its relationship with the ratio of observed-to-predicted rate of fire spread is not statistically significant $(r=-0.35 ; \mathrm{p}=0.566)$. Results suggest an actual steeper response of firespread rate to increasingly higher wind speeds, with $b>1$, although the number of observations is too meager to warrant a reexamination of the functional relationships in eqn. 1

The results indicate that by setting $a=2.041$ (the product of 0.773 and 2.64) eqn. 1 can be extended to fully developed wildfires under windier and drier conditions than those present in the experimental database. Similarly, Australian fire-spread models for eucalypt forest underestimated the rate of spread of large (ignition line $=120 \mathrm{~m}$ ) experimental fires by a factor of 2 to 3 (McCaw et al. 2008). Nonetheless, as data in Smith (1992) and Burrows et al. (2000) show, the 2.64 upscaling factor can still underestimate the rate of spread of surface fires in maritime pine stands. Note, however, that this concern is relevant only in tall, thinned and highpruned stands carrying low-to-moderate fuel loadings (e.g., Burrows et al. 2000). Under most other circumstances transition to crown fire will occur upon reaching substantially lower rates of spread, e.g., Fernandes et al. (2004); more open stands will also experience higher wind speeds and lower fuel moisture contents.

\section{Conclusion}

PIRoPinus provides estimates of fire behavior characteristics and fire effects for maritime pine stands in a user-friendly manner. A substantial advantage in relation to the options available is the ability to account for 
site-specific fuel and stand conditions (Fernandes et al. 2012). PiroPinus is fully compatible and can be linked with empirical models of crown fire initiation and spread, increasing the interest of its use in fire simulation modeling. While an interim adjustment factor for the spread rate of high-intensity wildfires is proposed here, future research should endeavor to develop a robust alternative to eqn. 1 with a wider scope of application.

\section{Acknowledgments}

Two anonymous reviewers provided useful comments and suggestions.

\section{References}

Ascoli D, Esposito A, Seneca U, Strumia S, Rutigliano FA, Catalanotti AE, Salgueiro A, Palheiro P, Rebelo A, Mazzoleni S, Bovio G, Fernandes P (2010). Using PiroPinus to assess fuel reduction effectiveness of prescribed burning in a Pinus halepensis plantation in southern Italy. In: Proceedings of the "VI International Conference on Forest Fire Research" (Viegas DX ed). ADAI, Coimbra, Portugal. [CD-ROM] Burrows N, Ward B, Robinson A (1988). Aspects of fire behaviour and fire suppression in a Pinus pinaster plantation. Landnote 2/88, Dept. of Conservation and Land Management of Western Australia, Perth, Australia.

Burrows N, Ward B, Robinson A (2000). Behaviour and some impacts of a large wildfire in the Gnangara maritime pine (Pinus pinaster) plantation, Western Australia. CALMScience 3: 251 260. [online] URL: http://www.cabdirect.org/abstracts/20000614216.html

Castedo-Dorado F, Gómez-Vázquez I, Fernandes
PM,Crecente-Campo F (2012). Shrub fuel characteristics estimated from overstory variables in NW Spain pine stands. Forest Ecology and Management 275: 130-141. - doi: 10.1016/j.foreco. 2012.03.002

Cheney NP, Gould JS (1995). Fire growth in grassland fuels. International Journal of Wildland Fire 5: 237-247. - doi: 10.1071/WF9950237 Fernandes P, Loureiro C, Botelho H, Ferreira A, Fernandes M (2002). Avaliação indirecta da carga de combustível em pinhal bravo. Silva Lusitana 10: 73-90. [in Portuguese]

Fernandes PM, Botelho HS, Rego FC, Loureiro C (2009). Empirical modelling of surface fire behaviour in maritime pine stands. International Journal of Wildland Fire 18: 698-710. - doi: 10.1071/WF08023

Fernandes PM, Loureiro C, Botelho H (2012). PiroPinus: a spreadsheet application to guide prescribed burning operations in maritime pine forest. Computers and Electronics in Agriculture 81: 58-61. - doi: 10.1016/j.compag.2011.11.005 Fernandes PM, Loureiro C, Botelho HS (2004). Fire behaviour and severity in a maritime pine stand under differing fuel conditions. Annals of Forest Science 61: 537-544. - doi: 10.1051/ forest:2004048

Ferreira O, Galante M (2003). Mata Nacional de Leiria, 2 e 3 de Agosto de 2003, Relatório de Ocorrência. DGF, Lisboa, Portugal. [in Portuguese]

Gould JS, Cheney NP, McCaw WL, Cheney S (2003). Effects of head fire shape and size on forest fire rate of spread. In: Proceedings of the " $3^{\text {rd }}$ International Wildland Fire Conference and Exhibition". Sydney (NSW, Australia) 3-6 October 2003.

Macedo FW, Sardinha AM (1987). Fogos flores- tais. Publicações Ciência e Vida, Lda., Lisboa, Portugal. [in Portuguese]

McArthur AG (1965). Fire behaviour characteristics of the Longford fire. Leaflet No. 91, Department of National Development, Forestry and Timber Bureau, Commonwealth of Australia.

McCaw WL, Gould JS, Cheney NP (2008). Existing fire behaviour models under-predict the rate of spread of summer fires in open jarrah (Eucalyptus marginata) forest. Australian Forestry 71 : 16-26. - doi: 10.1080/00049158.2008.10676267 Palheiro P, Fernandes P, Cruz M (2006). A fire behaviour-based fire danger classification for maritime pine stands: comparison of two approaches. Forest Ecology and Management 234: S54. - doi: 10.1016/j.foreco.2006.08.075

Smith R (1992). The Myalup wildfire, April 1991 - Observed fire behaviour and damage. CALM, Fire Protection Branch, Bunbury, Western Australia.

Sneeuwjagt RJ, Peet GB (1985). Forest fire behaviour tables for Western Australia. Department of Conservation and Land Management, Western Australia.

Sullivan AL (2009). Wildland surface fire spread modeling, 1990-2007. 2. Empirical and quasiempirical models. International Journal of Wildland Fire 18: 369-386. - doi: 10.1071/WF06142 Willmott CJ (1982). Some comments on the evaluation of model performance. Bulletin of the American Meteorological Society 63: 1309 1313. - doi: 10.1175/1520-0477(1982)063<13 09: $\mathrm{SCOTEO}>2.0 . \mathrm{CO} ; 2$

Wotton BM, McAlpine RS, Hobbs MW (1999). The effect of fire front width on surface fire behaviour. International Journal of Wildland Fire 9: 247-253 - doi: 10.1071/WF00021 